\title{
Perceived mutual impact of strategy and organizational structure: Findings from the high-technology enterprises
}

\section{AgnieszKa ZaKRZeWSKa-BielaWsKa}

\begin{abstract}
The paper aims to investigate the relationship between strategy and structure in the high-technology enterprises. The study attempts to ascertain how chief executive officers perceive the impact of strategy on organizational structure, and likewise impact of structure on strategy, at two phases in the innovation process: the phase of innovation exploration; and the phase of innovation exploitation. The research was conducted in 61 high-technology companies based in Poland that operate either in Poland or in the global marketplace. The results show that, during the exploration of innovation, chief executive officers consider that the impact of organizational structure on strategy is stronger than the impact of strategy on structure. During the exploitation of innovations, the impact of strategy on structure is stronger.
\end{abstract}

Keywords: innovation and $\mathrm{R} \& \mathrm{D}$, organizational structure, corporate strategy, quantitative methods, survey studies

Received 7 October 2014. Accepted 30 November 2015

\section{INTRODUCTION}

T $\mathrm{t}$ seems clear that a firm needs both to explore new possibilities to ensure profits for tomorrow and to 1 exploit old certainties for profits for today (March, 1991). Although exploration and exploitation are conflicting organizational processes (Benner \& Tushman, 2003) they are not mutually exclusive (He \& Wong, 2004). They are often understood as orthogonal activities (Gupta, Smith, \& Shalley, 2006; Uotila, Maula, Keil, \& Zahra, 2009; Russo \& Vurro, 2010), which interact positively, as both are necessary for the survival and development of an organization. Studies have shown that exploration (searching for new opportunities) and exploitation (refinement of existing competencies) require very different strategies and structures (e.g., O’Reilly \& Tushman, 2008; Boumgarden, Nickerson, \& Zenger, 2012). In general, it has been shown that exploration is associated with organic structures, path-breaking, and emerging markets and technologies, while exploitation is associated with mechanistic structures, path dependence, and stable markets and technologies (Brown \& Eisenhardt, 1998, Lewin, Long, \& Carroll, 1999; Ancona, Goodman, Lawrence, \& Tushman, 2001). Although some authors long ago indicated different structures and strategies for exploration and exploitation, there is some ambiguity about the relationship between strategy and structure at two phases in the innovation process (the phase of innovation exploration; and the phase of innovation exploitation) and a shortage of research in this area, especially if companies both explore and exploit at the same time. Therefore, there is a research gap regarding the need to identify the relationship and impact of strategy 
and organizational structure on each other in these two phases. In particular, I attempt to ascertain how and under what circumstances strategy affects structure, and likewise how and under what circumstances structure affects strategy in both exploration and exploitation innovation. It should be noted here that the relationship between a strategy and an organizational structure seen in this context has not been explored in research to date, which makes it an interesting cognitive issue.

Exploration and exploitation innovation have been widely defined in literature. Exploration innovation is often associated more with breakthroughs or radical innovations, with development of new products, creation of new markets, and the identification of needs for emerging customers and markets (Garcia, Calantone, \& Levine, 2003; Mom, Van den Bosch, \& Volberda, 2007). In turn, exploitation innovation is associated with incremental technological innovations or innovations intended to respond to current consumer needs, with extensions and refinements to existing products to satisfy customers in known markets, and existing operational processes in the firm (Jansen, Van den Bosch, \& Volberda, 2006; Bierly \& Daly, 2007; Andropoulos \& Lewis, 2009). In my study, the phase of innovation exploration refers to the pursuit of new opportunities in the spirit of invention and experimentation, while the phase of innovation exploitation relates to extensions and refinements to existing products and operational activities, as these typically evolve around interests of efficiency.

My paper aims to investigate the relationship between strategy and structure in the phase of exploration, and exploitation innovation based on the experiences and their impact as perceived by chief executive officers (CEOs) in high-technology (high-tech) enterprises. The choice of this sector is intentional. High-tech enterprises are innovative (Lazonick, 2010; Liefner, Wei, \& Zeng, 2013) and knowledge based (Kodama, 2006; Yang, 2012). In this type of enterprise, structures and strategies should primarily promote innovation and the creation of new knowledge (particularly technological knowledge in the form of patents and inventions); which reflects the exploration phase of innovation (Jayanthi \& Sinha, 1998; Garcia, Calantone, \& Levine, 2003; Sidhu, Commandeur, \& Volberda, 2007). On the other hand, the exploitation phase of innovation refers to extensions and refinements to existing product-market objectives and the efficiency of organizational structure in implementing them (He \& Wong, 2004; Wadhwa \& Kotha, 2006). Thereby, the two phases of innovation should take place in high-tech enterprises, which allows the discovery of new, mutual relations between their structure and strategies.

It should be emphasized that the high-tech sector is difficult to define because most new, advanced technologies exceed the boundaries of industries according to traditional classifications. It is usually assumed to comprise the sectors with a high dependence on science and technology (National Science Foundation), which rely on the results of processing research results in industry (Bessant, 2003). There is also a widespread understanding to include within the concept of the high-tech sector those industries and products which are characterized by a higher research and development (R\&D) intensity compared with other industries and products (Eurostat, 2013). Here, two main approaches are used to identify technological intensity: the sectoral approach ${ }^{1}$ and the product approach ${ }^{2}$. It should also be pointed out that, in addition to these industries and groups of products, high technologies are sometimes classified in a more aggregated way, namely by placing them into the following five basic categories: information technologies (electronics, information, and communication), biotechnologies,

1 The sectoral approach is based on the Statistical Classification of Economic Activities (NACE). This classification evaluates the technological intensity of sectors expressed as R\&D expenditure/value added, and classifies the sectors as high, medium, or low technology according to the score obtained. Services are also classified according to their technological intensity based on the number of highly qualified personnel. The high-tech sector total is the sum of high-tech manufacturing and high-tech knowledge-intensive services (Eurostat, 2013).

2 High-tech product groups are defined according to the R\&D intensity of products following the concepts developed by the OECD - R\&D expenditure/total sales. The groups classified as high-tech products are aggregated on the basis of the Standard International Trade Classification (Eurostat, 2013). 
material technologies (mainly nanotechnology), power technologies, and space technologies (Organization for Economic Co-operation and Development [OECD], 2013). Moreover, high-tech enterprises are characterized by a short life cycle of goods and processes, a rapid diffusion of innovation, an increasing demand for highly skilled staff, and close scientific and technological cooperation among enterprises and research centers within countries and internationally (NewCronos, 2009). In my study, I assume that high-tech enterprises are companies operating in a field recognized as high technology (according to Statistical Classification of Economic Activities [NACE]; the sectoral approach), combining the features of innovative and knowledge-based enterprises.

To determine the relationship between strategy and organizational structure in exploration and exploitation innovation, I used survey data gathered from 61 high-tech companies based in Poland, which operate either in Poland or in the global marketplace. My study contributes to the research in the field of strategic organizations in two key and specific aspects. First, it expands the current knowledge of the relationship between strategy and organizational structure (e.g., Chandler, 1962; Rumelt, 1974; Fredrickson, 1986; Mintzberg, 1990) with the aspect of innovation management by analyzing their mutual relations in the phases of innovation exploration and innovation exploitation (the theoretical contribution of the paper). Second, it indicates, based on CEOs' opinions, practical propositions on how strategy and organizational structure should be shaped in order to be conducive to high-tech enterprise development (the empirical contribution of the study).

The study is organized as follows. First, I define 'strategy' and 'organizational structure' in high-tech enterprises, taking into account modern approaches to strategies and organizational structures, and I show which of them are the most appropriate for high-tech enterprises due to their particular traits, in particular for exploration and exploitation innovation. Second, I determine the strength and direction of the impact of strategy on organizational structure and vice versa in the phases of innovation exploration and of innovation exploitation in high-tech companies. Third, taking into account various dimensions of strategy, the features of organizational structure, and the strength of their mutual influence, I present a pattern that fits strategy and organizational structure for high-tech enterprises, as well as for other less technologically advanced but innovative and knowledge-based enterprises, that is meant to enhance their success. This pattern has been expanded to include managerial implications.

\section{THE MULTIDIMENSIONAL NATURE OF STRATEGY-STRUCTURE RELATIONS IN HIGH-TECH ENTERPRISES: CONCEPT AND HYPOTHESES}

\section{The strategy of high-tech enterprises: Resources and opportunities}

The concept of strategy is ambiguous and is interpreted differently in the literature, what is evidenced by numerous schools and approaches to strategy (e.g., De Wit \& Meyer, 2005; Mintzberg, Ahlstrand, \& Lampel, 2009; Galvin \& Arndt, 2014). Because of this ambiguity and in order to better understand the essence of the strategies of high-tech companies, I carried out an expert survey in 2009. I selected a panel of 15 experts, including 11 well-known academics from Polish universities working in the field of strategic management, two representatives of consulting companies providing business consulting services for the high-tech sector, and two CEOs managing high-tech companies. The experts were asked to express their views (as comprehensively as was practically possible) regarding strategy in high-tech sector companies (I asked them five open-ended questions that focused, among other things, on indicating the most appropriate approach to strategy).

Due to the peculiarity of high-tech enterprises (i.e., their high level of innovation and development of new knowledge, particularly technological), most experts agreed that the two best approaches to strategy in such enterprises are the resource-based view (Smith, Vasudevan, \& Tanniru 1996; Barney, 2001; Lin, Lin, \& Bou-Wen, 2010; Lu \& Liu, 2013) and the approach based on opportunities 
(Alvarez \& Barney, 2007; Bingham \& Eisenhardt, 2008; Short, Ketchen, Shook, \& Ireland, 2010; Wood \& McKinley, 2010), because they require being flexible and pro-innovative.

The resource-based view assumes that the success of an organization lies within the organization itself, or to be exact - in its valuable, intangible, and not perfectly imitable resources (VRIO condition, ie. Valuable, Rare, costly to Imitate, Organized to capture value) allowing it to achieve a sustainable competitive advantage (Barney \& Clark, 2007). Resources are generally defined as 'all assets, capabilities, organizational processes, firm attributes, information, knowledge, etc. controlled by a firm' (Armstrong \& Shimizu, 2007; Barney \& Clark, 2007). In high-tech enterprises, due to their peculiarity, the most important is the availability of innovative resources, for example, know-how, patents, R\&D base (Chen, 2012; Pujol-Jover \& SerradellLopez, 2013), the competence, talents, creativity, and innovative skills of employees (Quintana-García \& Benavides-Velasco, 2008; Rasulzada \& Dackert, 2009), as well as partnership relationships with outside entities (Willoughby \& Galvin, 2005). The development of these innovative resources (especially technological knowledge) allows an enterprise to expand and change both its geographical and product areas, or to sell a specific resource in the form of a license, thus obviating the need to run a production facility.

The development of resource-based view is closely linked to the growing turbulence of the environment, because in the context of its unpredictability, resources and competences are a more stable base on which to generate strategies (Grant, 2003). Because the environment in which high-tech enterprises operate is unpredictable and complex (Gavetti, Levinthal, \& Rivkin, 2005; Davis, Eisenhardt, \& Bingham, 2009), such enterprises also need to be highly responsive in order to take advantage of opportunities, which require a redundancy of resources (i.e., creating an excess of resources, especially innovative ones). Moreover, the use of emerging opportunities and creation of new ones is possible, in accordance with the network paradigm (Borgatti \& Foster, 2003), through operation in heterogeneous interorganizational networks (Jarvenpaa \& Välikangas, 2014). Davis, Eisenhardt, and Bingham (2009) and Eisenhardt and Sull (2001) stated that strategy formulation in an opportunity context is best achieved using a strategic management artifact called simple rules. Brown and Eisenhardt (1997) indicated that high-tech firms with a moderate number of simple rules (i.e., semistructure) are more flexible and efficient - quickly creating high-quality, innovative products while responding to market shifts - than firms with more or fewer rules. Hence, opportunity strategy focuses on selecting a few strategic processes with deep and swift flows of opportunities and learning simple rules to take advantage of opportunities (Bingham \& Eisenhardt, 2008).

Taking into account the above views on strategy, it can be concluded that the development of technologies, innovations, and knowledge as resources (the resource-based view approach) provides the foundation for the strategy of high-tech enterprises when attempting to take advantage of fleeting opportunities, which reflects the exploration activities connected with invention, experimentation, and the search for new opportunities (Huff, Floyd, Sherman, \& Terjesen, 2009). The exploitation of these opportunities and full use of a firm's existing competencies determine, extend, and refine the product-market domains expressed most in terms of (1) the specialization and diversification of the product and market; (2) internal and/or external growth; and (3) the scope of vertical integration (Pearce \& Robinson, 2007; Johnson, Scholes, \& Whittington, 2008), which in turn mirrors exploitation activities.

\section{The organizational structure of high-tech enterprises: An ambidextrous approach}

The organizational structure of high-tech enterprises should make it possible for employees to perform creative tasks oriented toward the development of new knowledge (Nonaka \& Takeuchi, 1995; Hagel \& Brown, 2005), yet it should also enable them to perform routine actions efficiently (Daft, 2007). Moreover, high-tech enterprises should also be able to explore innovations and combine the optimal performance of operational units with the exploitation of innovations (Bessant, 2003). In light of this, the ambidextrous organizational design is the best approach for such enterprises, and arguments in support of this approach for innovative companies are well established in the literature 
(e.g., He \& Wong, 2004; O’Reilly \& Tushman, 2004; Andriopoulos \& Lewis, 2009; Cantarello, Martini, \& Nosella, 2012; Chandrasekaran, Linderman, \& Schroeder, 2012). Duncan (1976) was the first who used the term 'organizational ambidexterity.' He argued that for long-term success, firms needed to consider dual structures, with different structures to initiate and to execute innovation. In this view, also called 'temporal' or 'sequential' ambidexterity, exploitation and exploration are separated in time, with the organization moving from one prevailing approach to the other (Markides, 2013; O'Reilly \& Tushman, 2013). Over the years, scholars have identified other forms of ambidexterity known as: structural, contextual, and leadership (Nosella, Cantarello, \& Filipini, 2012; Birkinshaw \& Gupta, 2013; O’Reilly \& Tushman, 2013). In this study, I focus on structural ambidexterity, which allows the organization to explore and exploit innovations simultaneously (O'Reilly \& Tushman, 2004; Gilbert, 2005; Jansen, Tempelaar, Van den Bosch, \& Volberda, 2009), but demands different organizational architectures for these activities. Exploration requires decentralized structures, loose work processes, and a focus on experimentation, while exploitation needs highly structured roles and responsibilities, centralized procedures, and a focus on efficiency (Chen \& Kannan-Narasimhan, 2015). High-tech enterprises need structures that promote both exploration and exploitation innovation and cannot afford to be forced to choose either one or the other.

According to structural ambidexterity, exploration and exploitation are separated and coordinated by senior management (O’Reilly \& Tushman, 2004). Organizations create spatial separation, referred to as structural separation (Raisch \& Birkinshaw, 2008), at the business unit or corporate level. There are two types of subunit in the organization, one focusing primarily on exploration (e.g., R\&D), another on exploitation (e.g., manufacturing), with their integration occurring at the level of the entire organization (Benner \& Tushman, 2003; Jansen et al., 2009; Kortmann, 2012).

The literature frequently describes organizational structures conducive to innovative and knowledgebased companies through the prism of their features, such as specialization, standardization, configuration, centralization, formalization, and flexibility (e.g., Myers, 1996; O’Sullivan, Giraldo, \& Roman, 2010; Zelong, Yaqun, \& Changhong, 2011; Mahmoudsalehi, Moradkhannejad, \& Safari, 2012; Arora, Belenzon, \& Rios, 2014). Discussing the organizational structure features in accordance with the structural ambidextrous approach, numerous studies (e.g., Alder \& Borys, 1996; Jansen, Van den Bosch, \& Volberda, 2005; Wei, Yi, \& Yuan, 2011) recommend that enterprises adopt low formalization, high decentralization, and a flat hierarchy in the phase of innovation exploration, and to have an organic structure with little standardization and specialization. However, in the phase of innovation exploitation, the structure can be more bureaucratic; in this phase, the structure can have greater standardization and specialization, a higher level of formalization and centralization, and a taller hierarchy. These opposite structural features of exploration and exploitation subunits require integration at the senior level of management.

Besides organizational structure features, sometimes particular forms of organizational structure are indicated. For instance, Hedlund (1994) proposed an N-form corporation for knowledge-based firms. $\mathrm{He}$ added, however, that 'radical innovations are not achieved by (re)combination and experimentation only, and these innovations can be achieved through specialization, abstract articulation, and investment outside present competences' (Hedlund, 1994), that is through M-form structures. Daft (2007) also indicated that elements of design, process, and network structures are appropriate for innovative and knowledge-based companies. Specifically, the latter are characteristic of high-tech companies (Rank, Rank, \& Wald, 2006; Bertrand-Cloodt, Hagedoorn, \&Van Kranenburg, 2011; Helena Chiu, \& Lee, 2012), because the newest technologies require close cooperation, since today the success of one product depends on the contributions of many experts in different fields. In addition, gaining access to knowledge and the ability to innovate are often the primary aims of the creation and operation of interorganizational networks (Nambisan \& Sawhney, 2011; Chunlei, Rodan, Fruin, \& Xiaoyan, 2014). Therefore, the key feature of organizational structures in the modern economy is 
networking, understood as participation in interorganizational networks and the ability to reconfigure the systems of these networks (Moensted, 2010; Mukkala, 2010; Van Geenhuizen \& Nijkamp, 2012).

The organizational structure of high-tech enterprises that adopt a structural ambidextrous approach can be described as eclectic or hypertext (Nonaka \& Takeuchi, 1995; Menguc \& Auh, 2010). During innovation exploration, when new ideas are generated and new technologies are developed, the structure should be adaptable and have organic qualities (Galbraith, Downey, \& Kates, 2002). Conversely, during innovation exploitation, when production, trade, and financial tasks of a repetitive and routine nature are performed, the features of the organizational structure need to be more bureaucratic to ensure high efficiency (Hatch, 1997; Daft, 2007). Such a model of an ambidextrous organizational structure corresponds mainly to a high-tech company that runs both its own inventions and production and/or provides high-tech services (such enterprises were the subject of the research). In companies operating as research laboratories with external commercialization, the organizational structure covers mainly the exploration phase.

\section{The strategy-structure nexus in the phases of innovation exploration and innovation exploitation}

The relationship between strategy and organizational structure continues to be a significant and valid issue in strategic management (Galan \& Sanchez-Bueno, 2009). Chandler (1962), who advanced the thesis that structure follows strategy, was a forerunner in research on this relationship. Numerous subsequent studies have supported Chandler's proposition that strategic decisions and choices have a strong impact on and bring about changes in organizational structure (e.g., Rumelt, 1974; Galbraith \& Kazanjian, 1986; Hill \& Jones, 1992; Lament, Williams, \& Hoffman, 1994). However, others have argued that this relationship can be reversed, so that 'strategy follows structure' (e.g., Ansoff, 1979; Hall and Saias, 1980; Fredrickson, 1986; Mintzberg, 1990; Russo, 1991).

Due to the interaction between the strategy and the organizational structure and considering the differences between exploration and exploitation innovations, I propose two hypotheses.

Hypothesis 1: During the phase of innovation exploration, the impact of organizational structure on strategy is stronger than the impact of strategy on organizational structure.

In this phase, the organizational structure has to be organic to develop technologies, innovations, and knowledge as resources, and enhance the organization's ability to take advantage of opportunities (related to strategic exploration).

On the assumption that the foundation of the strategy of high-tech firms in the exploration phase of innovation consists of the development of technologies, innovations, and knowledge as resources, and the ability to take advantage of opportunities, the organizational structure ought to be conducive to such development. High flexibility in the organizational structure in the phase of innovation exploration can lead to greater motivation and more opportunities to generate new ideas (March, 1991; Raisch, Birkinshaw, Probst, \& Tushman, 2009; Bergfors \& Lager, 2011). This is because the organic structural features - a loose hierarchy, low standardization, nonfixed assignment of tasks, high decentralization, and low formalization - can lead to an increase in the creativity of employees and the development of talents and abilities to develop new knowledge (Andriopoulos \& Lewis, 2009; Tushman, Smith, Wood, Westerman, \& O’Reilly, 2010).

Conversely, the lack of flexibility in the organizational structure (i.e., a more bureaucratic structure) in the phase of innovation exploration can inhibit creativity and reduce innovation and entrepreneurship (Hagel \& Brown, 2005; Daft, 2007), thereby counteracting the development of a pool of redundant key resources that are required to take advantage of fleeting opportunities. 
It can be concluded that such a strategy, understood as a continuous and dynamic process of making choices in conditions of uncertainty and of maintaining redundant development potential in order to take advantage of opportunities, requires organic and flexible organizational structures at the initial stage. However, it is the maintenance of this flexibility as the firm develops and grows that becomes a determinant of the implementation of such a strategy. An inappropriately rigid organizational structure may restrict strategic changes, reducing the firm's adaptive capacity and thus its ability to take advantage of opportunities; hence in this phase the impact of structure on strategy would appear to be greater than the impact of strategy on structure.

Hypothesis 2: During the phase of innovation exploitation, the impact of strategy on organizational structure is stronger than the impact of organizational structure on strategy.

The emergent product-market strategy forces changes to particular features of the organizational structure, which are conducive to operational efficiency and the performance of routine tasks.

A product-market strategy is determined, extended, and refined by the full use of a firm's existing competencies and results from a company's exploitation of resources and taking advantage of opportunities. In this case, the strong impact of strategy on organizational structure is evident (Chandler, 1962), and it becomes necessary to implement appropriate structural changes. On the other hand, the effect of organizational structure on strategy manifests itself in the capacity of the structure to make these changes (Mintzberg, 1990). Therefore, the subunit of the organizational structure concerned with innovation exploitation and the performance of routine activities (i.e., financial, production, trade, etc.) must also have a degree of flexibility and adaptability, even though its main task is to stabilize the business and achieve operational efficiency.

Different in nature, the phases of innovation exploration and exploitation result in various impacts of strategy on organizational structure and vice versa. It should be also noted that many exogenous and endogenous factors influence the relationship between the elements of strategy and of organizational structure in high-tech enterprises. These factors affect each of these two elements individually as well as their interrelations with each other. This paper focuses specifically on the latter, namely, the impact that the elements of strategy and structure have on each other. In order to test the above hypotheses in relation to high-tech enterprises, a survey was conducted of 61 selected companies in Poland in 2011. The following section describes the sample and the methods of data collection and analysis.

\section{METHODS}

\section{Sample}

For the study, I selected participants on the basis of two criteria

- That the company belonged to the high-tech enterprise sector (according to the OECD classification sectoral approach, i.e., high-tech industries as manufacturers of basic pharmaceutical products and pharmaceutical preparations, manufacturers of computers, electronic and optical products, and manufacturers of air, spacecraft, and related machinery; and high-tech knowledge-intensive services as telecommunications, computer programming, consultancy, and related activities, information service activities, scientific R\&D (High-technology and knowledge based services aggregations based on NACE Rev.2., 2012).

- That the company was classified as a medium (over 49 employees) or large enterprise (over 249 employees) (the act on freedom of economic activity, Polish legislation, 2004). Medium and large enterprises were selected because their organizational structures are more complex and formal. 
I selected the companies from the Teleadreson database ${ }^{3}$ on the basis of these criteria. From a total of 689 medium and large high-tech enterprises ${ }^{4}$, I invited 180 companies to take part in the survey ${ }^{5}$. In total, 61 agreed to participate: 24 from the information technology and telecommunications industries, 13 from the pharmaceutical industry, and 24 from other segments in the high-tech sector. In total, 47 of these companies were classified as medium enterprises and 14 as large enterprises. All 61 companies were based in Poland during the study period; 29 operated solely in Poland, and 32 operated globally. Each of the companies had a R\&D department. The companies were characterized by a high level of innovation, rapid of innovation, and a high proportion of scientific and technical staff ${ }^{6}$; in short, they shared many characteristics of high-tech enterprises (NewCronos, 2009).

\section{Data collection and measurements}

I conducted the survey using an interview method and within it a standardized interview technique. I used a standardized interview questionnaire (closed questions) as the research tool. The interview technique made it possible for the interviewed participants and I to come to an agreement as to the understanding of various concepts and phenomena (Zikmund, Babin, Carr, \& Griffin, 2013). The respondents were CEOs and the company was the level of analysis. I interviewed a number of CEOs (two to three persons) who expressed their opinions (sometimes varying) in relation to the questions asked. However, in their interaction with me, they agreed on a common position, which I marked in a prepared questionnaire. Therefore, the answers given do not reflect the opinion of a single CEO, but opinions of the board and top management in the company.

The interview questionnaire included 65 alternative, disjunctive, and conjunctive questions on the following five areas:

1. the characteristics of the company as a high-tech enterprise and an assessment of the conditions of its development;

2. the identification of features of the company's strategy;

3. the identification of features of the organizational structure;

4. the identification and assessment of the relationship between strategy and organizational structure; and

5. the CEO's assessment of the management of the strategy-structure relationship.

This paper presents an analysis of the survey results regarding the fourth area under consideration (i.e., the relationship between strategy and organizational structure). The algorithm used to identify the interrelations between strategy and organizational structure is shown in Figure 1.

The extant literature suggests that organizational structure has multiple features and it is through the lens of these features, and not the specific types, that the organizational structures of high-tech companies were studied. Researchers from Aston University in Birmingham (Pugh \& Hickson, 1976) identified the features of organizational structure as specialization, standardization, configuration,

3 Teleadreson is an electronic database with the contact details of companies operating in Poland, which can be identified using NACE codes.

4 In 2011 in Poland, there were 503 medium (from 50 to 249 employees) and 186 large (more than 249 employees) registered enterprises classified according to NACE Rev. 2 as high-tech companies (statistical data from the Central Statistical Office in Warsaw, 2012).

5 These were the companies which have carried out their own high-tech inventiveness and their own production or services, which were identified on the basis of public information and reports as Polish Market for ICT-Teleinfo 500, 2009 and Polish Pharmaceutical Market, 2009.

6 These characteristics were identified as a result of the conducted research. 
Perceived mutual impact of strategy and organizational structure

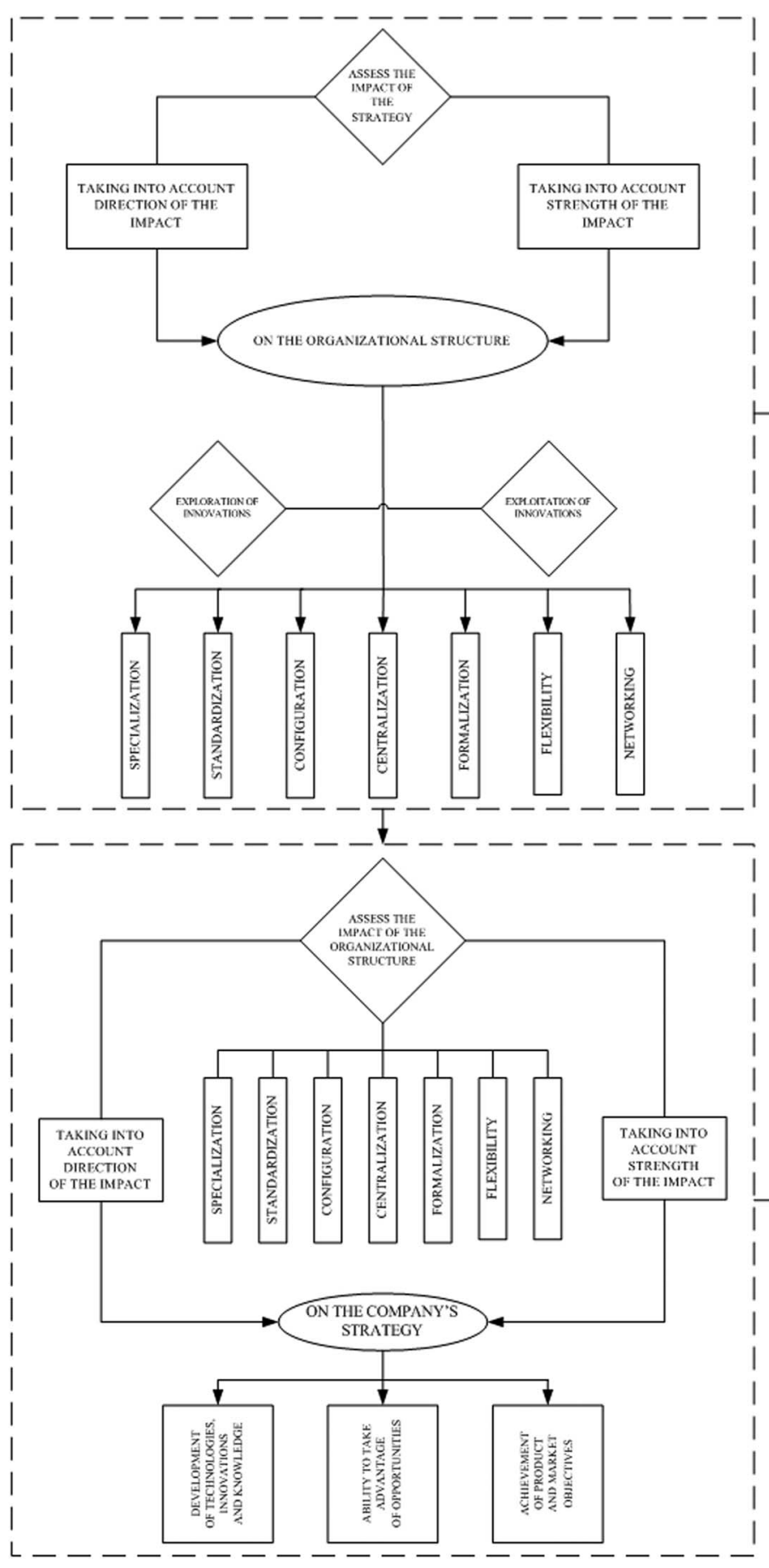

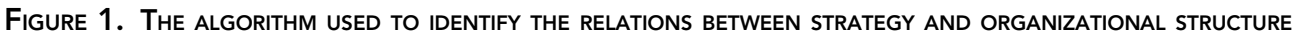


centralization, and formalization. Damanpour (1991) provides an extensive list of such features, including specialization, functional differentiation, professionalism, formalization, centralization, vertical differentiation, and other culture-, process-, and resource-related variables. Mintzberg (1993) recognizes such key issues that have to be addressed in organization design as vertical and horizontal work specialization, unit (job/department) groupings, planning, control and liaison systems, vertical and horizontal decentralizing, and coordinating the company's employees' work. Germain (1996) uses specialization, decentralization, and integration to evaluate the role of organizational structure in the adoption of logistics innovation. The Strategor (2001) group employ specialization, coordination, and formalization to represent the features of organizational structure. Nahm, Vonderembse, and Koufteros (2003) hypothesize five structural dimensions as follows: the number of layers in the hierarchy, the level of horizontal integration, the locus of decision making, the nature of formalization, and the level of communication. Thus far, the literature on features of organizational structure varies widely. There is no universal agreement on the features that should be used to conceptualize organizational structure, and researchers sometimes have named similar features differently. In this study, I follow the Aston group measures (Pugh \& Hickson, 1976) and consider the following five of the most commonly mentioned features:

1. specialization, which means the sophistication level of tasks and knowledge;

2. standardization, which means the typicality of actions, repeatability of procedures, unwritten habits;

3. configuration, which means the degree of diversification of roles and positions vertically and horizontally, and coordination methods;

4. centralization, which means the degree of centralization of decision-making authority; and

5. formalization, which means the number of formal documents, rules and procedures.

Due to the dynamics of the environment and the networking paradigm (Borgatti \& Foster, 2003; Fowler \& Reisenwitz, 2013), I propose and add two new variables:

6. flexibility, which means quickness and ease of introducing changes (Verdu \& Gomez-Gras, 2009; Bahrami \& Evans, 2011; Dunford, Cuganesan, Grant, Palmer, Beaumont, \& Steele, 2013);

7. networking, which means participation in interorganizational networks and the ability to reconfigure the systems of these networks (Moensted, 2010; Mukkala, 2010; Van Geenhuizen \& Nijkamp, 2012).

Based on the information from the interview and with the CEOs' consent, I determined these structural features by assigning each of them a single variant (state), separately for the innovation exploration and innovation exploitation phases. For the sake of simplicity, I assumed two possible variants (states) for each feature, namely (1) specialization: broad or narrow, (2) standardization: high or low, (3) configuration: predominantly vertical or predominantly horizontal, (4) centralization: high or low, (5) formalization: high or low, (6) flexibility: high or low, (7) networking: independence or participation in interorganizational networks. It should be noted here that the organic structural features are reflected by broad specialization, low standardization, predominantly horizontal forms of task integration, low centralization and formalization, high flexibility (Burns \& Stalker, 1961), and participation in interorganizational networks. The opposite states of organizational structure features reveal bureaucratic structures (Daft, 2007).

Using the algorithm shown in Figure 1, the impact of strategy on structure was assessed in the phases of innovation exploration and innovation exploitation, in accordance with the adopted structural ambidexterity approach (O'Reilly \& Tushman, 2004). I took into account both the strength of the impact and its direction, that is, the direction toward which these seven specific features of the organizational structure evolved as a result of the strategic decisions made (e.g., whether formalization increased or decreased). 
I assessed also the strength and direction of the impact of the seven specific features of the organizational structure on company strategy regarding

1. the development of technologies, innovations, and knowledge as resources;

2. the ability to take advantage of opportunities; and

3. the product-market strategy.

This assessment also determined whether the impact of these features was positive or negative (i.e., whether the level of centralization was conducive to the development of technologies, innovations, and knowledge as resources, or whether it inhibited such development).

When I was measuring the interaction of strategy and organizational structure, I used the 5-point Likert scale ( 1 = 'very low impact;' 5 = 'very high impact'). I used this scale to assess (1) the strength of impact of the strategy and structure on each other, (2) the strength of impact of the strategy on the highlighted features of the organizational structure, and (3) the strength and direction of the impact of the features of the organizational structure on the highlighted dimensions of the strategy. In contrast, I measured the direction of impact of the strategy on the organizational structure through the lens of the changes in the distinguished features of the organizational structure.

A comprehensive analysis of how the CEOs assessed the strength and direction of the impact of these seven features on the three areas of strategy provided a broad picture of the relationship between the strategy and the organizational structure perceived by top management.

It should be noted that, in order to account for the time factor in the evaluation of the impact of strategy on structure and vice versa, the respondents were asked to answer the questions from the perspective of at least 3 years of operation.

\section{Analysis}

The interviews conducted using the questionnaire resulted in the accumulation of a large volume of data that were subsequently organized, grouped, and analyzed. I used the statistical factors and descriptive statistics, as well as a Spearman's correlation, the Kruskal-Wallis tests, Mann-Whitney tests, Friedman tests, and $\chi^{2}$ tests $^{7}$ as the methods of analysis, the application of which allowed me to identify significant differences in the answers of CEOs according to the high-tech industry and company size.

It should be noted that reliance on the subjective assessments of the respondents constitutes a certain limitation (Podsakoff \& Organ, 1986) with respect to the obtained results.

However, because the respondents were CEOs, it is reasonable to assume that their responses reflect the situation in their respective companies to the greatest possible extent. Moreover, I often conducted the interviews in groups of two or three CEOs, who viewed the investigated phenomena subjectively but in the course of discussion reached a common viewpoint, which I took as the variable characterizing the given issue.

\section{RESULTS AND DISCUSSION}

First, the overall impact of strategy on structure and structure on strategy was assessed for (1) the phase of innovation exploration, and (2) the phase of innovation exploitation (Table 1). My aim here was to learn about the general feelings and opinions of the CEOs regarding the strength of the impact of the two elements, strategy and structure.

7 The use of statistical tests for a nonrandom sample was just an attempt to discern the differences between the respondents' answers compared with the studied relations, and was not meant to generalize the results in the whole population. 
Table 1. The Chief executive officers' (CEOs) assessment of the StRength of the IMPACt of StRategy on ORGANIZATIONAL STRUCTURE AND OF THE IMPACT OF STRUCTURE ON STRATEGY IN THE PHASES OF INNOVATION EXPLORATION AND INNOVATION EXPLOITATION

\begin{tabular}{|c|c|c|c|c|c|c|c|}
\hline \multirow[b]{2}{*}{ Impact } & \multicolumn{3}{|c|}{ Phase of innovation exploration } & \multicolumn{3}{|c|}{ Phase of innovation exploitation } & \multirow[b]{2}{*}{ Comparison } \\
\hline & $\bar{x}$ & M & $Q$ & $\bar{x}$ & M & Q & \\
\hline Of strategy on structure & 3.2 & 3 & 1 & 3.6 & 4 & 1 & $z=2.710 ; p<.05$ \\
\hline Of structure on strategy & 3.7 & 4 & 1 & 3.2 & 3 & 1 & $z=3.414 ; p<.01$ \\
\hline Comparison & \multicolumn{3}{|c|}{$z=3.452 ; p<.01$} & \multicolumn{3}{|c|}{$z=2.671 ; p<.05$} & $H=22.321 ; p<.001$ \\
\hline
\end{tabular}

Note. CEOs were asked to assess the strength of the impact using the $1-5$ Likert scale ( 1 = 'very low impact'; $5=$ 'very high impact').

$M=$ median; $Q=$ quantities deviation; $\bar{x}=$ average.

A statistically significant difference was found between respondents' assessments concerning the mutual influence of strategy and organizational structure in the exploration and exploitation phases of innovation in the surveyed firms $(H=22.321 ; p<.001)$. The pairwise comparison of the results showed the difference in results for the exploration phase of innovation to be significant at an error level of $p<.01$. The impact of structure on strategy $(M=4)$ was significantly stronger than the impact of strategy on structure $(M=3)$. In turn, in the innovation exploitation phase strategy has a stronger impact on structure $(M=4)$ than structure on strategy $(M=3)$. In this case, the difference is found to be significant at a higher error level $(p<.05)$. A comparison was also made of the size of the impact of strategy on structure in the two analyzed phases, which showed that the impact was greater in the exploitation phase than in the exploration phase $(M=4$ vs. $M=3)$, the difference being statistically significant $(p<.05)$. Similarly, the comparison of the impact of structure on strategy in these two phases also revealed a statistically significant difference $(p<.01)$ - here the impact was found to be significantly stronger in the exploration phase of innovation than in the exploitation phase $(M=4$ vs. $M=3)$.

The results of the Kruskal-Wallis tests showed that there were no significant differences according to industry type and company size, which means that, irrespective of the size of the firm and the sector in which it operates, respondents always assessed the impact of structure on strategy as higher in the exploration phase of innovation, and the impact of strategy on structure as higher in the exploitation phase.

To check whether there were significant relationships between the assessments of the strength of impact of strategy on organizational structure and of structure on strategy in the exploration and exploitation phases of innovation, Spearman's correlations were obtained (Table 2).

The results of the analysis showed that several relationships were significant $(p<.05)$ and positively correlated. The strongest correlation was between the impact of strategy on organizational structure in the exploitation phase of innovation, and the impact of structure on strategy in the exploration phase $(R=0.50)$. This means that if the impact of strategy on structure in the exploitation phase was rated as strong, then the impact of structure on strategy in the exploration phase was also rated as strong. There is also a strong positive correlation between the impact of strategy on structure in the exploration phase of innovation and its impact in the exploitation phase $(R=0.49)$, and between the impact of organizational structure on strategy in the exploration phase and its impact in the exploitation phase $(R=0.46)$. This means that if a respondent considered strategy to have a strong impact on organizational structure in the exploration phase of innovation, the respondent also considered its impact to be strong in the innovation exploitation phase of innovation. Similarly, if CEOs considered the impact of organizational structure to be strong in the exploration phase of innovation, that impact would also be rated as strong in the exploitation phase. 
Table 2. Spearman's correlations between the strength of the impact of StRategy on organizational STRUCTURE AND OF THE IMPACT OF STRUCTURE ON STRATEGY IN THE PHASES OF INNOVATION EXPLORATION AND INNOVATION EXPLOITATION

\begin{tabular}{lccc}
\hline \hline & $\begin{array}{c}\text { Of strategy on structure in } \\
\text { the innovation exploitation } \\
\text { phase }\end{array}$ & $\begin{array}{c}\text { Of structure on strategy in } \\
\text { the innovation exploration } \\
\text { phase }\end{array}$ & $\begin{array}{c}\text { Of structure on strategy in } \\
\text { the innovation exploitation } \\
\text { phase }\end{array}$ \\
\hline $\begin{array}{l}\text { Of strategy on structure in } \\
\text { the innovation exploration } \\
\text { phase }\end{array}$ & 0.49 & 0.28 & 0.09 \\
$\begin{array}{l}\text { Of strategy on structure in } \\
\text { the innovation } \\
\text { exploitation phase } \\
\text { Of structure on strategy in } \\
\text { the innovation exploration } \\
\text { phase }\end{array}$ & 0.50 & 0.10 \\
\hline
\end{tabular}

Note. $R \geq 0.28$ is essential with minimum $p<.05$ identified by bold values.

The above leads to the conclusion that in the exploration phase of innovation, even when there is a strong impact of strategy on structure, the impact of structure on strategy is stronger; conversely, in the exploitation phase of innovation, even when there is a strong impact of structure on strategy, the impact of strategy on structure is stronger. Therefore, the obtained results confirm the first part of the proposed hypotheses.

In the case of innovation exploration, the impact of strategy on the features of the organizational structure (specialization, standardization, configuration, centralization, formalization, flexibility, and networking) was greatest on the structural features of centralization, flexibility, and networking. In the case of innovation exploitation, strategy had the greatest impact on the structural features of specialization, configuration, centralization, formalization, and flexibility. Differences between the innovation exploration and innovation exploitation phases proved statistically significant in the case of specialization $\left(\chi^{2}=13.496 ; p<.01\right)$, configuration $\left(\chi^{2}=9.167 ; p<.05\right)$, formalization $\left(\chi^{2}=43.928 ; p<.001\right)$, and networking $\left(\chi^{2}=36.277 ; p<.001\right)$. This is shown in Table 3 .

Taking into account the direction of this impact (Table 4), it can be stated that in the case of innovation exploration a statistically significant difference was recorded in the impact of strategy on different variables related to structure $(p<.001)$. Strategy mainly increased the flexibility of the organizational structure through greater specialization, less hierarchy, and more decentralization. In the case of innovation exploitation, the impact of strategy on organizational structure was very diverse, making the structure more flexible and giving it more organic qualities, as well as making it more bureaucratic. Here too, the differences in the impact on different features of structure proved statistically significant $(p<.001)$, although the relationships were weaker. However, in many companies, the CEOs stated that the particular features of the organizational structure studied in this paper did not change as a result of the implemented strategy. Rather, the CEOs argued that the elements (strategy and structure) were matched and there was no need to change the organizational structure. Respondents indicated here that small changes were taking place in their firms all the time, but these were not significant enough to cause a radical change in any particular features of the organizational structure.

The comparison of the direction of changes in the phase of innovation exploration with changes in the phase of exploitation revealed statistically significant differences in terms of increased flexibility of structure through a less constant division of tasks in the exploration phase $\left(\chi^{2}=10.614 ; p<.01\right)$, 


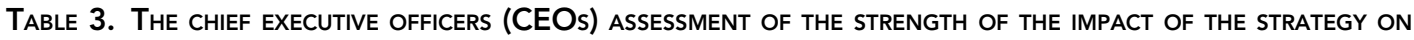
THE FEATURES OF ORGANIZATIONAL STRUCTURE IN THE PHASES OF INNOVATION EXPLORATION AND INNOVATION EXPLOITATION

\begin{tabular}{|c|c|c|c|c|c|c|}
\hline \multirow[b]{2}{*}{ Impact of the strategy on } & \multicolumn{3}{|c|}{ Phase of innovation exploration } & \multicolumn{3}{|c|}{ Phase of innovation exploitation } \\
\hline & Weak (N) & Moderate $(N)$ & Strong (N) & Weak (N) & Moderate $(N)$ & Strong $(N)$ \\
\hline Specialization & 14 & 35 & 12 & 11 & 19 & 31 \\
\hline Standardization & 18 & 34 & 9 & 14 & 36 & 11 \\
\hline Configuration & 15 & 33 & 13 & 6 & 28 & 27 \\
\hline Centralization & 10 & 28 & 23 & 3 & 29 & 29 \\
\hline Formalization & 38 & 19 & 4 & 5 & 30 & 26 \\
\hline Flexibility & 18 & 21 & 22 & 8 & 21 & 32 \\
\hline Networking & 1 & 4 & 18 & 18 & 23 & 3 \\
\hline Comparison & \multicolumn{3}{|c|}{$\chi^{2}=88.276 ; p<.001 ; C=0.43$} & \multicolumn{3}{|c|}{$\chi^{2}=61.138 ; p<.001 ; C=0.36$} \\
\hline
\end{tabular}

Note. CEOs were asked to assess the strength of the impact using the $1-5$ Likert scale ( 1 = 'very low impact;' $5=$ 'very high impact'). Sorting was carried out in such a way that all scores 1 and 2 for a particular relationships were classified as poor impact, score 3 as moderate impact, and scores 4 and 5 as strong impact.

$N=$ number of companies.

Table 4. Direction of the impact of StRategy on the features of organizational Structure in the phases of EXPLORATION INNOVATION AND EXPLOITATION OF INNOVATION

\begin{tabular}{|c|c|c|c|c|c|c|c|}
\hline \multicolumn{6}{|c|}{ Impact of strategy on the features of organizational structure $(N)$} & \multicolumn{2}{|c|}{ No changes $(\mathrm{N})$} \\
\hline & Ep & Es & & Ep & Es & Ep & Es \\
\hline More fixed assignment of tasks & 2 & 12 & Less fixed assignment of tasks & 23 & 12 & 36 & 37 \\
\hline Narrower nature of tasks & 14 & 3 & Broader nature of tasks & 12 & 16 & 35 & 42 \\
\hline Higher standardization of actions & 12 & 14 & Lower standardization of actions & 11 & 7 & 38 & 40 \\
\hline Taller hierarchy & 1 & 2 & Flatter hierarchy & 14 & 7 & 46 & 52 \\
\hline Higher centralization of decisions & 4 & 10 & Higher decentralization of decisions & 12 & 5 & 45 & 46 \\
\hline Greater number of formal rules & 7 & 11 & Smaller number of formal rules & 4 & 3 & 50 & 47 \\
\hline Lower flexibility of the structure & - & 4 & Higher flexibility of the structure & 24 & 12 & 37 & 45 \\
\hline Exiting the organization network & - & - & Entering the organization networks & 5 & 2 & 56 & 59 \\
\hline $\begin{array}{l}\text { Comparison for Ep } \\
\text { Comparison for Es }\end{array}$ & \multicolumn{7}{|c|}{$\begin{array}{l}\chi^{2}=68.767 ; p<.001 ; C=0.35 \\
\chi^{2}=46.958 ; p<.001 ; C=0.30\end{array}$} \\
\hline
\end{tabular}

Note. $\mathrm{Ep}=$ phase of innovation exploration; $\mathrm{Es}=$ phase of innovation exploitation; $N=$ number of companies.

narrower specialization of tasks in that phase $\left(\chi^{2}=8.325 ; p<.05\right)$, and significantly greater flexibility of structure $\left(\chi^{2}=8.781 ; p<.05\right)$.

From the analysis of the strength and direction of the impact of the features of organizational structure on strategy (Table 5), the following can be stated:

1. The CEOs indicated that all the features of organizational structure affected strategy.

2. Structure exerted the strongest impact on the development of technologies, innovations, and knowledge as resources, in particular through the structural features of specialization and flexibility $(M=4)$. 
TAble 5. The strength AND direction of the impact of the features of Organizational structure on STRATEGY

Positive (favorable) impact of the organizational Negative (hindering, impeding) impact of the organizational structure structure

$\begin{array}{lllllllllllllllll}\mathrm{Sp} & \mathrm{St} & \mathrm{Co} & \mathrm{Cn} & \mathrm{Fr} & \mathrm{Fl} & \mathrm{Nt} & \mathrm{Sp} & \mathrm{St} & \mathrm{Co} & \mathrm{Cn} & \mathrm{Fr} & \mathrm{Fl} & \mathrm{Nt}\end{array}$

\begin{tabular}{|c|c|c|c|c|c|c|c|c|c|c|c|c|c|c|}
\hline \multicolumn{15}{|c|}{ On the development of technologies, innovations, and knowledge } \\
\hline$N$ & 60 & 60 & 61 & 57 & 54 & 61 & 23 & 1 & 1 & 0 & 4 & 7 & 0 & 0 \\
\hline $\bar{x}$ & 3.4 & 2.8 & 3.1 & 3.0 & 2.9 & 3.3 & 3.2 & - & - & - & - & - & - & - \\
\hline M & 4 & 3 & 3 & 3 & 3 & 4 & 3 & - & - & - & - & - & - & - \\
\hline Q & 1 & 0 & 2 & 2 & 2 & 1 & 1 & - & - & - & - & - & - & - \\
\hline \multicolumn{15}{|c|}{ On the ability to take advantage of opportunities } \\
\hline N & 61 & 59 & 61 & 50 & 52 & 55 & 15 & 0 & 2 & 0 & 11 & 9 & 6 & 0 \\
\hline $\bar{x}$ & 3.3 & 2.5 & 2.7 & 2.7 & 2.9 & 3.6 & 2.2 & - & - & - & -1.5 & - & - & - \\
\hline$M$ & 3 & 3 & 3 & 3 & 3 & 4 & 2 & - & - & - & -1 & - & - & - \\
\hline Q & 1 & 1 & 1 & 3 & 2 & 0 & 2 & - & - & - & 1 & - & - & - \\
\hline \multicolumn{15}{|c|}{ On product-market objectives } \\
\hline$N$ & 60 & 59 & 60 & 58 & 45 & 60 & 20 & 1 & 2 & 1 & 3 & 16 & 1 & 0 \\
\hline $\bar{x}$ & 2.8 & 2.2 & 2.3 & 2.7 & 2.0 & 2.4 & 2.1 & - & - & - & - & -1.4 & - & - \\
\hline$M$ & 3 & 2 & 3 & 3 & 2 & 2.5 & 1 & - & - & - & - & -1 & - & - \\
\hline$Q$ & 2 & 1 & 1 & 1 & 1 & 1 & 2 & - & - & - & - & 1 & - & - \\
\hline
\end{tabular}

Note. Chief executive officers were asked to assess the strength and direction of the impact using the scoring scale from -5 to +5 , where $-5=$ 'very high negative impact;' $-1=$ 'very low negative impact;' $0=$ 'no impact; $+1=$ 'very low positive impact;' $+5=$ 'very high positive impact.' Due to the small number of companies where the impact of studied features of the organizational structure on strategy was assessed as being negative, calculation of an average and median is not methodologically correct. Therefore, in these cases only the numbers of companies were given. Moreover, the companies where there has been no impact (' $O$ ' score) were excluded from these calculations, which is why the numbers of companies differ in the case of networking.

$\mathrm{Cn}=$ centralization; $\mathrm{Co}=$ configuration; $\mathrm{Fl}=$ flexibility; $\mathrm{Fr}=$ formalization; $M=$ median; $N=$ number of companies; $\mathrm{Nt}=$ networking; $\mathrm{Q}=$ quantities deviation; $\mathrm{Sp}=$ specialization; $\mathrm{St}=$ standardization; $\bar{x}=$ average.

Only in isolated cases was the development of these resources hindered by structural conditions, in particular by high centralization of decisions and formal documents, rules, and procedures.

3. The ability to seize opportunities was improved to the greatest extent by the structural feature of flexibility, whereas high levels of centralization and formalization greatly restricted this ability.

4. The weakest impact of structure was observed in relation to product-market strategy. According to the interviewed CEOs, too much formalization hindered the implementation of this strategic aspect.

I carried out Mann-Whitney tests at this point, taking into account the states of individual features of organizational structure in the innovation exploration and innovation exploitation phases (Table 6), and the assessment of the strength and direction of the impact of individual features on the selected dimensions of strategy. It should be noted that individual structural features in the exploration phase were tested together with the evaluation of their impact on the development of technologies, innovations, and knowledge as resources, as well as on the organization's ability to take advantage of opportunities (as these dimensions describe the strategy in this phase). The organizational structure features in the innovation exploitation phase were tested along with the evaluation of their impact on the strategy, as reflected by product-market goals. 
TAble 6. The Chief executive officers' (CEOs) assessment of the features of ORganizational Structure in THE PHASES OF INNOVATION EXPLORATION AND INNOVATION EXPLOITATION

\begin{tabular}{|c|c|c|}
\hline Features of organizational structure & Phase of innovation exploration (N) & Phase of innovation exploitation (N) \\
\hline \multicolumn{3}{|l|}{ Specialization } \\
\hline Narrow & 25 & 17 \\
\hline Wide & 36 & 44 \\
\hline \multicolumn{3}{|l|}{ Standardization } \\
\hline Low & 41 & 30 \\
\hline High & 20 & 31 \\
\hline \multicolumn{3}{|l|}{ Configuration } \\
\hline Vertical domination & 37 & 58 \\
\hline Horizontal domination & 24 & 3 \\
\hline \multicolumn{3}{|l|}{ Centralization } \\
\hline Low & 22 & 8 \\
\hline High & 39 & 53 \\
\hline \multicolumn{3}{|l|}{ Formalization } \\
\hline Low & 39 & 10 \\
\hline High & 22 & 51 \\
\hline \multicolumn{3}{|l|}{ Flexibility } \\
\hline Low & 14 & 35 \\
\hline High & 47 & 26 \\
\hline \multicolumn{3}{|l|}{ Networking } \\
\hline Independence & 38 & 17 \\
\hline Participation in networks & 23 & 44 \\
\hline
\end{tabular}

Note. During the interview, CEOs answered individual questions about the features of organizational structure separately for the innovation exploration and innovation exploitation phases. Subsequently, I determined these features based on the obtained information and with the acceptance of the CEOs, by assigning each of them a separate single variant (state) for the innovation exploration and innovation exploitation phases.

$N=$ number of companies.

The results of individual analyses showed statistically significant differences $(p<.05)$ in the case of a vast majority of examined relations, which made it possible to draw the following conclusions:

1. The more organic the structural features (low levels of standardization, centralization, formalization, predominantly horizontal configuration, high flexibility, and participation in interorganizational networks), the more the impact of organizational structure on the development of technology, innovation, and knowledge as resources was seen as stronger and more positive.

2. The more organic the structural features were (broad specialization, low level of standardization, centralization, formalization, predominantly horizontal configuration, high flexibility, and participation in interorganizational networks), the more the impact of organizational structure was seen as stronger and more conducive to taking advantage of opportunities.

3. The greater the flexibility of organizational structure was (other features were not statistically significant, at $p>.05)$, the more its impact on the realization of product-market goals was seen as stronger and more positive.

Overall, this study shows that in CEOs' opinions strategy leads to changes in structure and structure leads to changes in strategy. These findings have already been presented by many other researchers (e.g., Chandler, 1962; Ansoff, 1979; Mintzberg, 1990). However, the new approach to the problem presented here results from the specificity of the high-tech sector and the necessity to analyze these 
relations from the perspectives of the exploration and exploitation of innovations. Moreover, the strategy of these high-tech companies is not based on a long-term plan (this long-term plan was considered in Chandler, 1962). Instead, their strategy is defined in terms of strategic resources (Barney, 2001) and the ability to take advantage of opportunities (Eisenhardt \& Sull, 2001; Davis, Eisenhardt, \& Bingham, 2009) during the innovation exploration phase, and in terms of product-market choices in the innovation exploitation phase. In addition, the organizational structure of these companies can be characterized as structurally ambidextrous, which makes it possible for such companies to be more successful if the structure is organic in the phase of innovation exploration, and more bureaucratic in the phase of innovation exploitation (O'Reilly \& Tushman, 2004; Jansen, Van den Bosch, \& Volberda, 2005).

The adopted approach made it possible to identify new interrelations between strategy and structure. Although the sample was deliberate, making it impossible to generalize conclusions from the survey, the conducted research strongly suggests that, according to CEOs' opinions, 'strategy follows structure' during the phase of innovation exploration. That is to say, structure influences the development of key resources and the ability to take advantage of opportunities in high-tech companies. The more organic the features of the organizational structure, the greater the impact of structure on strategy. Conversely, Chandler's thesis that 'structure follows strategy' works in the phase of innovation exploitation, a phase that includes the performance of routine business activities. This is so because the features of organizational structure are more bureaucratic in this phase. Nevertheless, the organizational structure has to have some flexibility in order to be able to adapt to take advantage of the identified and subsequently exploited opportunities, which can in turn change the product-market objectives. Therefore, the proposed hypotheses are supported by the survey results.

\section{CONCLUSION AND IMPLICATIONS FOR MANAGEMENT PRACTICE}

An inadequate organizational structure can frustrate efforts related to development activities. In the case of high-tech enterprises, which focus on innovation and scientific and technological progress, it is often observed that the organizational structure lags behind the mission and strategy (Daft, 2007). Hence, successful high-tech enterprises attempt to implement an organizational structure that will make it possible, on the one hand, to ensure that their employees have the necessary independence and freedom to generate new ideas and, on the other, to have the necessary control over the entire enterprise (Menguc \& Auh, 2010). This could be achieved by separating structural subunits for exploration and exploitation, and as O'Reilly and Tushman (2013) suggested, each with its own alignment of people, structure, processes, and cultures, but with targeted integration to ensure the use of resources and capabilities. These different subunits should cooperate, and being integrated at the high management level, the senior team should manage the conflicts and interface issues that such a design entails (O'Reilly \& Tushman, 2008). How leaders balance the pressures of different organizational architectures and manage interfaces between exploration and exploitation is not a subject of this study. Although some scholars have taken up this issue (e.g., Lubatkin, Simsek, Ling, \& Veiga, 2006; Jansen, Vera, \& Grossan, 2009; Binns, Smith, \& Tushman, 2011) it is still an interesting direction for future research (Cao, Simsek, \& Zhang, 2010; O'Reilly \& Tushman, 2013).

On the basis of the results of the survey (CEOs' perceived mutual impact of structure and strategy), I propose a pattern for fitting and shaping the relations between strategy and organizational structure in high-tech companies (Figure 2), which may also be applicable for other innovative companies.

As indicated in Figure 2, in the phase of innovation exploration, strategy is expressed in terms of resources (Barney \& Clark, 2007) and opportunities (Alvarez \& Barney, 2007; Wood \& McKinley, 2010). Such a strategy should be very flexible. The company must have the ability to experiment and 
EXPLORATION OF INNOVATIONS

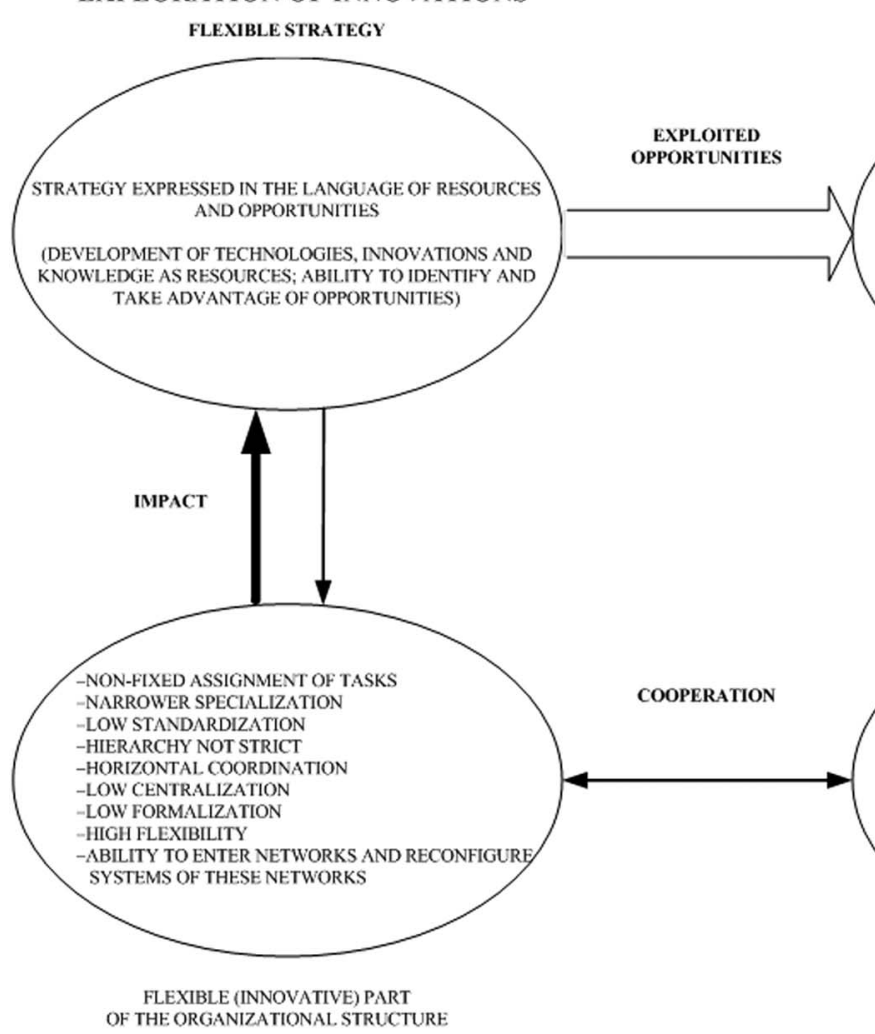

EXPLOITATION OF INNOVATIONS

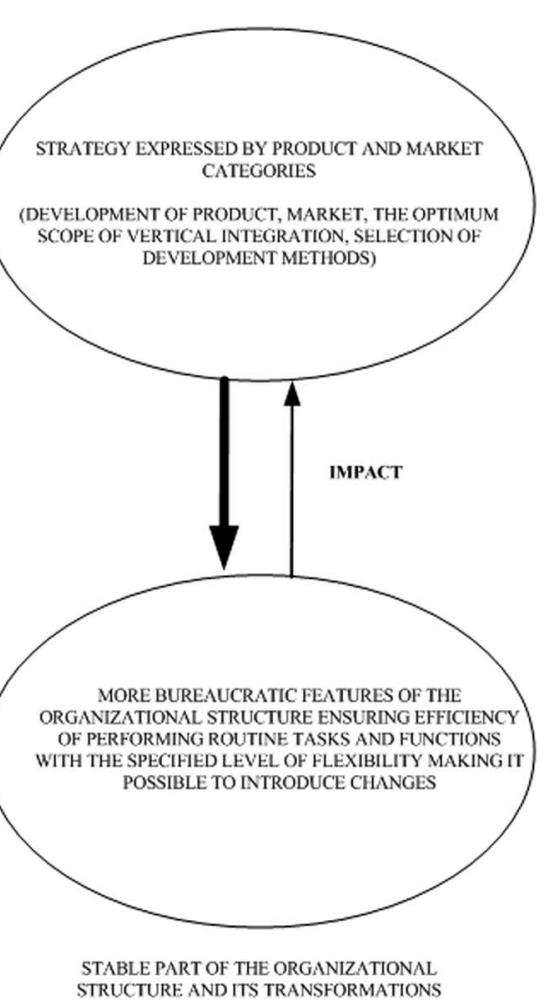

Figure 2. Pattern for shaping the strategy and organizational structure Relations in High-technology ENTERPRISES

generate ideas, have a redundancy of resources (especially technologies, innovations, and knowledge), and be able to identify and take advantage of opportunities. This type of strategy must coexist with a flexible structure characterized by highly organic features. The organic structure has been identified as fundamental in exploring and exploiting new opportunities to innovate in hypercompetitive environments (Volberda, 1996; Hatum \& Pettigrew, 2006). To a large extent, maintaining this flexibility determines the implementation of such a strategy (as stated above, structure has a stronger impact on strategy at the phase of innovation exploration) and promotes the development of the company. The ideas generated and accepted are then implemented and the exploited opportunities affect the product-market strategy.

In the phase of innovation exploitation, the structure can be more bureaucratic, making it possible to ensure that routine activities are performed in a highly efficient way (O'Reilly \& Tushman, 2011). However, this structure cannot be fixed because it would be difficult to make any further changes that might be necessary as a result of the emerging and exploited opportunities. Moreover, the larger, more diverse, and more complex the enterprise, the greater the need for flexibility is.

The resulting basic managerial implications for CEOs can be summed up in the following points:

1. Both strategy and organizational structure in high-tech enterprises should be determined from the perspective of exploration and exploitation activities. 
2. In the exploration phase of innovation, organizational structure should have very organic features, because this strongly determines the formation of flexible resource- and opportunity-oriented strategies, rather than product-market goals.

3. In the exploitation phase of innovation, the strategy expressing the product-market goals, resulting from the opportunities taken, strongly determines the organizational structure, which may be more bureaucratic to ensure the efficient implementation of activities.

4. CEOs should continually monitor and improve the alignment of the strategy and organizational structure by implementing the necessary changes in the dynamic perspective, as well as reconcile tensions arising between exploration and exploitation activities (Raisch et al., 2009), which will ensure their further development.

The discussion presented here does not cover all the issues related to the concept of strategy-structure relations, and the study has its limitations. First, the impact of strategy on structure and of structure on strategy was determined based on the opinions of CEOs, which are subjective by nature. Second, the data concern CEOs opinions, so we can only discuss the perceived mutual impact of strategy and structure. Thus, further research could be conducted into these identified relations by using additional, more objective instruments, and longitudinal analysis. It would also be interesting to undertake research on the impact of other variables (e.g., environment, size, age, life cycle, culture, technological advancement, and so on) on the direction and strength of the interrelations between strategy and organizational structure.

In conclusion, I hope that this paper will provide inspiration for continuing research on strategy, organizational structure, and strategy-structure relations as sources of innovation in high-tech companies, which are crucial to ensuring the competitiveness of particular regions and nations.

\section{ACKNOWLEDGEMENT}

This research was supported by Ministry for Science and Higher Education Grant NN115 128434 awarded to Agnieszka Zakrzewska-Bielawska.

\section{References}

Alder, P. S., \& Borys, B. (1996). Two types of bureaucracy: Enabling and coercive. Administrative Science Quarterly, 41(1), 61-89.

Alvarez, S. A., \& Barney, J. B. (2007). Discovery and creation: Alternative theories entrepreneurial action. Strategic Entrepreneurship Journal, 1(1-2), 11-26.

Ancona, D. G., Goodman, P. S., Lawrence, B. S., \& Tushman, M. L. (2001). Time: A new research lens. Academy of Management Review, 26(4), 645-663.

Andriopoulos, C., \& Lewis, M. W. (2009). Exploitation-exploration tensions and organizational ambidexterity: Managing paradoxes of innovation. Organization Science, 20(4), 696-717.

Anonymous (2009). High-technology and knowledge based services aggregations based on NACE Rev.2. Retrieved October 10, 2012, from http://epp.eurostat.ec.europa.eu/cache/ITY_SDDS/Annexes /htec_esms_an3.pdf.

Ansoff, H. I. (1979). Strategic management. London: Macmillan Press.

Armstrong, C. E., \& Shimizu, K. (2007). A Review of approaches to empirical research on the resource-based view of the firm. Journal of Management, 33(6), 959-986.

Arora, A., Belenzon, S., \& Rios, L. (2014). Make, buy, organize: The interplay between research, external knowledge, and firm structure. Strategic Management Journal, 35(3), 317-337.

Bahrami, H., \& Evans, S. (2011). Super-flexibility for real-time adaptation: Perspectives from Silicon Valley. California Management Review, 53(3), 21-39.

Barney, J. B. (2001). Is the resource-based view a useful perspective for strategic management research? Yes. Academy of Management Review, 26(1), 41-56. 
Barney, J. B., \& Clark, D. N. (2007). Resource-based theory: Creating and sustaining competitive advantage. New York: Oxford University Press.

Benner, M. J., \& Tushman, M. L. (2003). Exploitation, exploration, and process management: The productivity dilemma revisited. Academy of Management Review, 28(2), 238-256.

Bergfors, M., \& Lager, T. (2011). Innovation of process technology: Exploring determinants for organizational design. International Journal of Innovation Management, 15(5), 1113-1140.

Bertrand-Cloodt, D., Hagedoorn, J., \& Van Kranenburg, H. (2011). The strength of R\&D network ties in high-tech sectors-a multi-dimensional analysis of the effects of tie-strength on innovative performance. Technology Analysis \& Strategic Management, 23(10), 1015-1030.

Bessant, J. (2003). High involvement innovation. Chichester: John Wiley \& Sons Ltd.

Bierly, P. E., \& Daly, P. S. (2007). Alternative knowledge strategies, competitive environment, and organizational performance in small manufacturing firms. Entrepreneurship Theory and Practice, 31(4), 493-516.

Bingham, C. B., \& Eisenhardt, K. M. (2008). Position, leverage and opportunity: A typology of strategic logics lining resources with competitive advantage. Managerial and Decision Economics, 29(2-3), 241-256.

Binns, A., Smith, W. K., \& Tushman, M. L. (2011). The ambidextrous CEO. Harvard Business Review, 89(6), 74-80.

Birkinshaw, J., \& Gupta, K. (2013). Clarifying the distinctive contribution of ambidexterity to the field of organization studies. The Academy of Management Perspectives, 27(4), 287-298.

Borgatti, S. R., \& Foster, R. C. (2003). The network paradigm in organizational research: A review and typology. Journal of Management, 29(6), 991-1013.

Boumgarden, P., Nickerson, J., \& Zenger, T. R. (2012). Sailing into the wind: Exploring the relationships among ambidexterity, vacillation, and organizational performance. Strategic Management Journal, 33(6), 587-610.

Brown, S. L., \& Eisenhardt, K. M. (1997). The art of continuous change: Linking complexity theory and time-paced evolution in relentlessly shifting organizations. Administrative Science Quarterly, 42(1), 1-34.

Brown, S. L., \& Eisenhardt, K. M. (1998). Competing on the edge: Strategy as structured chaos. Boston, MA: Harvard Business School Press.

Burns, T., \& Stalker, G. M. (1961). The management of innovation. London: Tavistock.

Cantarello, S., Martini, A., \& Nosella, A. (2012). A multi-level model for organizational ambidexterity in the search phase of the innovation process. Creativity and Innovation Management, 21(1), 28-48.

Cao, Q., Simsek, Z., \& Zhang, H. (2010). Modeling the joint impact of the GEO and the TMT on organizational ambidexterity. Journal of Management Studies, 47(7), 1272-1296.

Chandler, A. D. (1962). Strategy and Structure. Cambridge, MA: MIT Press.

Chandrasekaran, A., Linderman, K., \& Schroeder, R. (2012). Antecedents to ambidexterity competency in high technology organizations. Journal of Operations Management, 30(1), 134-151.

Chen, R. R., \& Kannan-Narasimhan, R. P. (2015). Formal integration archetypes in ambidextrous organizations. R\&D Management, 45(3), 267-286.

Chen, T. F. (2012). Transforming knowledge into action to reach innovation capacity in high-tech SMEs. International Journal of Innovation \& Technology Management, 9(1), 1250005_1-12500_32.

Chunlei, W., Rodan, S., Fruin, M., \& Xiaoyan, X. (2014). Knowledge networks, collaboration networks, and exploratory innovation. Academy of Management Journal, 57(2), 454-514.

Daft, R. L. (2007). Understanding the theory and design of organizations. Mason, OH: Thomson South-Western Mason.

Damanpour, F. (1991). Organizational innovation: A meta-analysis of effects of determinants and moderators. Academy of Management Journal, 34(3), 555-590.

Davis, J. P., Eisenhardt, K. M., \& Bingham, C. B. (2009). Optimal structure, market dynamism, and the strategy of simple rules. Administrative Science Quarterly, 54(3), 413-452.

De Wit, B., \& Meyer, R. (2005). Strategy synthesis: Resolving strategy paradoxes to create competitive advantage. London: Thompson Learning.

Duncan, R. (1976). The ambidextrous organization: Designing dual structures for innovation. In R. Kilman, \& L. Pondy (Eds.) The management of organizational design (pp. 167-188). New York, NY: North Holland.

Dunford, R., Cuganesan, S., Grant, D., Palmer, I., Beaumont, R., \& Steele, C. (2013). Flexibility as the rationale for organizational change: A discourse perspective. Journal of Organizational Change Management, 26(1), 83-97. 
Eisenhardt, K. M., \& Sull, D. N. (2001). Strategy as simple rules. Harvard Business Review, 79(1), 106-116.

Eurostat (2013). Science, technology and innovation in Europe. Luxembourg: Office of the European Union. Retrieved March 25, 2015, from http://ec.europa.eu/eurostat/documents/39302 97/5969406/KS-GN-13-001-EN.PDF.

Fowler, J. G., \& Reisenwitz, T. H. (2013). A review of interfirm networks: A deeper understanding of the relationships paradigm. Journal of Business Strategies, 30(1), 21-64.

Fredrickson, J. W. (1986). The strategic decision process and organizational structure. Academy of Management Review, $11(2), 280-297$.

Galan, J. I., \& Sanches-Bueno, M. J. (2009). The continuing validity of the strategy-structure nexus: New findings, 1993-2003. Strategic Management Journal, 30(11), 1234-1243.

Galbraith, J., Downey, D., \& Kates, A. (2002). Designing dynamic organizations: A hands-on guide for leaders at all levels. New York, NY: Amacom.

Galbraith, J., \& Kazanjian, R. K. (1986). Strategy implementation: Structure, systems and process. St. Paul, MN: West Publishing.

Galvin, P., \& Arndt, F. (2014). Strategic management: Building depth as well as breadth. Journal of Management \& Organization, 20(2), 139-147.

Garcia, R., Calantone, R., \& Levine, R. (2003). The role of knowledge in resource allocation to exploration versus exploitation in technologically oriented organizations. Decision Sciences, 34(2), 323-349.

Gavetti, G., Levinthal, D., \& Rivkin, J. W. (2005). Strategy making in novel and complex worlds: The power of analogy. Strategic Management Journal, 26(8), 691-712.

Germain, R. (1996). The role of context and structure in radical and incremental logistics innovation adoption. Journal of Business Research, 35(2), 117-127.

Gilbert, C. G. (2005). Unbundling the structure of inertia: Resource versus routine rigidity. Academy of Management Journal, 48(5), 741-763.

Grant, R. (2003). Strategic planning in a turbulent environment: Evidence from the oil majors. Strategic Management Journal, 24(6), 491-517.

Gupta, A. K., Smith, K. G., \& Shalley, C. E. (2006). The interplay between exploration and exploitation. Academy of Management Journal, 49(4), 693-706.

Hagel, J., \& Brown, J. S. (2005). The only sustainable edge: Why business strategy depends on productive friction and dynamic specialization. Boston, MA: Harvard Business School Press.

Hall, D. J., \& Saias, M. A. (1980). Strategy follows structure. Strategic Management Journal, 1(2), 149-163.

Hatch, M. J. (1997). Organization theory: Modern, symbolic, and postmodern perspectives. Oxford: Oxford University Press.

Hatum, A., \& Pettigrew, M. (2006). Determinants of organizational flexibility: A study in an emerging economy. British Journal of Management, 17(2), 115-137.

He, Z. L., \& Wong, P. K. (2004). Exploration vs. exploitation: An empirical test of the ambidexterity hypothesis. Organization Science, 15(4), 481-494.

Hedlund, G. (1994). A model of knowledge management and the N-form corporation. Strategic Management Journal, 15(Special Issue), 73-90.

Helena Chiu, Y., \& Lee, T. (2012). Structural embeddedness and innovation performance: Capitalizing on social brokerage in high-tech clusters. Innovation: Management, Policy \& Practice, 14(3), 337-348.

Hill, C., \& Jones, G. (1992). Strategic management theory. Boston, MA: Houghton Mifflin.

Huff, A. S., Floyd, S. W., Sherman, H. D., \& Terjesen, S. (2009). Strategic management: Logic and action. New York, NY: John Wiley\& Sons.

Jansen, J. J. P., Tempelaar, M. P., Van den Bosch, F. A., \& Volberda, H. W. (2009). Structural differentiation and ambidexterity: The mediating role of integration mechanisms. Organization Science, 20(4), 797-811.

Jansen, J. J. P., Van den Bosch, F. A. J., \& Volberda, H. W. (2005). Exploratory innovation, exploitative innovation, and ambidexterity: The impact of environmental and organizational antecedents. Schmalenbach Business Review, 57(4), 351-363.

Jansen, J. J. P., Van den Bosch, F. A. J., \& Volberda, H. W. (2006). Exploratory innovation, exploitative innovation, and performance: Effects of organizational antecedents and environmental moderators. Management Science, 52(11), $1661-1674$. 
Jansen, J. J. P., Vera, D., \& Grossan, M. (2009). Strategic leadership for exploration and exploitation: The moderating role of environmental dynamism. Leadership Quarterly, 20(1), 5-18.

Jarvenpaa, S., \& Välikangas, L. (2014). Opportunity creation in innovation networks: Interactive revealing practices. California Management Review, 57(1), 67-87.

Jayanthi, S., \& Sinha, K. K. (1998). Innovation implementation in high technology manufacturing: A chaos-theoretic empirical analysis. Journal of Operations Management, 16(4), 471-494.

Johnson, G., Scholes, K., \& Whittington, R. (2008). Exploring corporate strategy. Text and cases. Harlow: Financial Times Prentice Hall.

Kodama, M. (2006). Knowledge-based view of corporate strategy. Technovation, 26(12), 1390-1406.

Kortmann, S. (2012). The relationship between organizational structure and organizational ambidexterity: A comparison between manufacturing and service firms. Muenster, Germany: Springer.

Lament, B. T., Williams, R. J., \& Hoffman, J. J. (1994). Performance during $m$-form reorganization and recovery time: The effects of prior strategy and implementation speed. Academy of Management Journal, 37(1), 153-166.

Lazonick, W. (2010). The Chandlerian corporation and the theory of innovative enterprise. Industrial and Corporate Change, 19(2), 317-349.

Lewin, A. Y., Long, C. P., \& Carroll, T. N. (1999). The coevolution of new organizational forms. Organization Science, 10(5), 535-550.

Liefner, I., Wei, Y., \& Zeng, G. (2013). The innovativeness and heterogeneity of foreign-invested high-tech companies in Shanghai. Growth \& Change, 44(3), 522-549.

Lin, E., Lin, T. M. Y., \& Bou-Wen, L. (2010). New high-tech venturing as process of resource accumulation. Management Decision, 48(8), 1230-1246.

Lu, L. Y. Y., \& Liu, J. S. (2013). An innovative approach to identify the knowledge diffusion path: The case of resourcebased theory. Scientometrics, 94(1), 225-246.

Lubatkin, M. H., Simsek, Z., Ling, Y., \& Veiga, J. F. (2006). Ambidexterity and performance in small- to mediumsized firms: The pivotal role of TMT behavioral integration. Journal of Management, 32(5), 646-672.

Mahmoudsalehi, M., Moradkhannejad, R., \& Safari, K. (2012). How knowledge management is affected by organizational structure. Learning Organization, 19(6), 518-528.

March, J. G. (1991). Exploration and exploitation in organizational learning. Organization Science, 2(1), 71-87.

Markides, C. C. (2013). Business model innovation: What can the ambidexterity literature teach us? The Academy of Management Perspectives, 27(4), 313-323.

Menguc, B., \& Auh, S. (2010). Development and return on execution of product innovation capabilities: The role of organizational structure. Industrial Marketing Management, 39(5), 820-831.

Mintzberg, H. (1990). The design school: Reconsidering the basic premises of strategic management. Strategic Management Journal, 11(3), 171-195.

Mintzberg, H. (1993). Structure in fives: Designing effective organizations. Englewood Cliffs, NY: Prentice Hall.

Mintzberg, H., Ahlstrand, B., \& Lampel, J. (2009). Strategy safari. Your complete guide through the wilds of strategic management. Edinburgh: Financial Times Prentice Hall.

Moensted, M. (2010). Networking and entrepreneurship in small high-tech European firms: An empirical study. International Journal of Management, 27(1), 16-30.

Mom, T. J. M., Van den Bosch, F. A. J., \& Volberda, H. W. (2007). Investigating managers' exploration and exploitation activities: The influence of top-down, bottom-up, and horizontal knowledge inflows. Journal of Management Studies, 44(6), 910-931.

Mukkala, K. (2010). The role of regional policies in promoting networking and innovative activity: Evidence from small Finnish high-tech firms. European Planning Studies, 18(7), 1057-1076.

Myers, P. S. (Ed.) (1996). Knowledge management and organizational design. Boston, MA: Butterworth-Heinemann.

Nahm, A. Y., Vonderembse, M. A., \& Koufteros, X. A. (2003). The impact of organizational structure on time-based manufacturing and plant performance. Journal of Operations Management, 21(3), 281-306.

Nambisan, S., \& Sawhney, M. (2011). Orchestration processes in network-centric innovation: Evidence from the field. Academy of Management Perspectives, 25(3), 40-57.

NewCronos (2009). High-tech statistics - progress report. Doc.Eurostat/F4/STI/2009/11. Working Group Meeting on Statistics on Science, Technology and Innovation. Luxembourg. 
Nonaka, I., \& Takeuchi, H. (1995). The knowledge-creating company: How Japanese companies create the dynamics of innovation. New York, NY: Oxford University Press.

Nosella, A., Cantarello, S., \& Filippini, R. (2012). The intellectual structure of organizational ambidexterity: A bibliometric investigation into the state of the art. Strategic Organization, 10(4), 450-465.

Organization for Economic Co-operation and Development (OECD) (2013). OECD science, technology and industry scoreboard 2013. Innovation for growth. OECD Publishing. Retrieved October 7, 2014, from http://dx.doi.org/ 10.1787/sti_scoreboard-2013-en.

O'Reilly, C. A., \& Tushman, M. L. (2004). The ambidextrous organization. Harvard Business Review, 82(4), 74-81.

O'Reilly, C. A., \& Tushman, M. L. (2008). Ambidexterity as a dynamic capability: Resolving the innovator's dilemma. Research in Organizational Behavior, 28, 185-206.

O’Reilly, C. A., \& Tushman, M. L. (2011). Organizational ambidexterity in action. California Management Review, 53(4), 5-21.

O'Reilly, C. A., \& Tushman, M. L. (2013). Organizational ambidexterity: Past, present, and future. The Academy of Management Perspectives, 27(4), 324-338.

O'Sullivan, K. J., Giraldo, J. P., \& Roman, J. A. (2010). The function of knowledge management system in large-scale organizational design. In A. Green, M. Stankosky, \& L. Vandergriff (Eds.), Search knowledge management (pp. 71-88). Bingley, UK: Emerald Group Publishing Limited.

Pearce, J. A., \& Robinson, R. B. (2007). Strategic management. New York, NY: McGraw-Hill.

Podsakoff, P. M., \& Organ, D. W. (1986). Self-reports in organizational research: Problems and prospects. Journal of Management, 12(4), 531-544.

Pugh, D. S., \& Hickson, D. J. (1976). Organizational structure in its context. The Aston programme I. Westmead: Saxson House.

Pujol-Jover, M., \& Serradell-Lopez, E. (2013). How to build innovative knowledge high-tech companies: An exploratory analysis of 22@ companies, Proceedings of the International Conference on Intellectual Capital, Knowledge Management \& Organizational Learning, January 2013, 9, pp. 344-350.

Quintana-García, C., \& Benavides-Velasco, C. A. (2008). Innovative competence, exploration and exploitation: The influence of technological diversification. Research Policy, 37(3), 492-507.

Raisch, S., \& Birkinshaw, J. (2008). Organizational ambidexterity: Antecedents, outcomes, and moderators. Journal of Management, 34(3), 375-409.

Raisch, S., Birkinshaw, J., Probst, J., \& Tushman, M. L. (2009). Organizational ambidexterity: Balancing exploitation and exploration for sustained performance. Organization Science, 20(4), 685-695.

Rank, C., Rank, O., \& Wald, A. (2006). Integrated versus core-periphery structures in regional biotechnology networks. European Management Journal, 24(1), 73-85.

Rasulzada, F., \& Dackert, I. (2009). Organizational creativity and innovation in relation to psychological well-being and organizational factors. Creativity Research Journal, 21(2/3), 191-198.

Rumelt, R. P. (1974). Strategy, structure and economic performance. Cambridge, MA: Harvard University Press.

Russo, A., \& Vurro, C. (2010). Cross-boundary ambidexterity: Balancing exploration and exploitation in the fuel cell industry. European Management Review, 7(1), 30-45.

Russo, M. V. (1991). The multidivisional structure as an enabling device: A longitudinal study of discretionary cash as a strategic resource. Academy of Management Journal, 34(3), 718-733.

Short, J. C., Ketchen, D. J., Shook, C. L., \& Ireland, R. D. (2010). The concept of 'opportunity' in entrepreneurship research: Past accomplishments and future challenges. Journal of Management, 36(1), 40-65.

Sidhu, J. S., Commandeur, H. R., \& Volberda, H. W. (2007). The multifaceted nature of exploration and exploitation: Value of supply, demand, and spatial search for innovation. Organization Science, 18(1), 20-38.

Smith, K. A., Vasudevan, S. P., \& Tanniru, M. R. (1996). Organizational learning and resource-based theory: An integrative model. Journal of Organizational Change Management, 9(6), 41-53.

Strategor (2001). Management of company. Strategies, structures, decisions, identity. Warsaw: Polskie Wydawnictwo Ekonomiczne.

Tushman, M., Smith, W. K., Wood, R. C., Westerman, G., \& O’Reilly, C. (2010). Organizational designs and innovation streams. Industrial \& Corporate Change, 19(5), 1331-1366. 
Uotila, J., Maula, M., Keil, T., \& Zahra, S. A. (2009). Exploration, exploitation and financial performance: Analysis of S\&P 500 corporations. Strategic Management Journal, 30(2), 221-231.

Van Geenhuizen, M., \& Nijkamp, P. (2012). Knowledge virtualization and local connectedness among young globalized high-tech companies. Technological Forecasting \& Social Change, 79(7), 1179-1191.

Verdu, A. J., \& Gomez-Gras, J. M. (2009). Measuring the organizational responsiveness through managerial flexibility. Journal of Organizational Change Management, 22(6), 668-690.

Volberda, H. W. (1996). Toward the flexible form: How to remain vital in hypercompetitive environments. Organization Studies, 7(4), 359-374.

Wadhwa, A., \& Kotha, S. (2006). Knowledge creation through external venturing: Evidence from the telecommunications equipment manufacturing industry. Academy of Management Journal, 49(4), 819-835.

Wei, Z., Yi, Y., \& Yuan, C. (2011). Bottom-up learning, organizational formalization, and ambidextrous innovation. Journal of Organizational Change Management, 24(3), 314-329.

Willoughby, K., \& Galvin, P. (2005). Inter-organizational collaboration, knowledge intensity, and the sources of innovation in the bioscience-technology industries. Knowledge, Technology \& Policy, 18(3), 56-73.

Wood, M. S., \& McKinley, W. (2010). The production entrepreneurial opportunity: A constructivist perspective. Strategic Entrepreneurship Journal, 4(1), 66-84.

Yang, J. (2012). Innovation capability and corporate growth: An empirical investigation in China. Journal of Engineering \& Technology Management, 29(1), 34-46.

Zelong, W., Yaqun, Y., \& Changhong, Y. (2011). Bottom-up learning, organizational formalization, and ambidextrous innovation. Journal of Organizational Change Management, 24(3), 314-329.

Zikmund, W., Babin, B., Carr, J., \& Griffin, M. (2013). Business research methods. Mason, OH: South-Western Cengage Learning. 